\title{
The consummation of the kingdom of God Reflections on the final victory of Christ as portrayed in Paul's first Epistle to the Corinthians
}

\author{
Pieter Potgieter \\ Dean: Faculty of Theology \\ University of the Free State \\ BLOEMFONTEIN \\ E-mail: pcp.stg@mail.uovs.ac.za
}

\begin{abstract}
The consummation of the kingdom of God. Reflections on the final victory of Christ as portrayed in Paul's first Epistle to the Corinthians Reflections on 1 Corinthians 15:24-28 raise the question whether eschatology should be focused on Christ, or should rather be viewed theocentrically. A study of the mediatory reign of Christ clearly favours the notion of an intermediate kingdom, during which He will subjugate and destroy the "powers" and the enemies of the kingdom. Having achieved the final victory over death itself, the need for an intermediate rule of Christ no longer exists. However, the office of Mediator is unquestionably linked to Christ's humanity. This again brings to the fore the question whether Christ will retain his human nature after the consummation of his kingdom. Although it remains an open question in Reformed theology whether Christ will relinquish his human nature at the end of this dispensation, it is argued that in the next dispensation $\mathrm{He}$ will no longer serve in the office of Mediator, but that He will reign as the Lamb of God in the stature of the eternal Son of God.
\end{abstract}

\section{Introduction}

In theological reflection during the course of the twentieth century the kingdom of God was an often-recurring theme. It is quite clear that the final word on several related issues has not been spoken, particularly on the topic of the consummation of the kingdom. This area in itself is so wide-ranging that it is by no means possible to cover the whole field in a single article. I have therefore restricted myself to an investigation of a very specific reference to it in Paul's First Epistle to the Corinthians: chapter 15 verses 24-28. 
24. Then the end will come, when he (Christ) hands over the kingdom to God the Father after he has destroyed all dominion, authority and power.

25. For he must reign until he has put all his enemies under his feet.

26. The last enemy to be destroyed is death.

27. For he 'has put everything under his feet'. Now when it says that 'everything' has been put under him, it is clear that this does not include God himself, who put everything under Christ.

28. When he has done this, then the Son himself will be made subject to him who put everything under him, so that God may be all in all (NIV).

The history of Christianity clearly demonstrates that there were, and still are, many unsolved questions in this regard. Way back in the fourth century Cyril of Jerusalem conceded that this was so (Cat. Lect. X.9), while more recently Berkouwer posed the question whether eschatology should not be viewed theocentrically rather than Christocentrically (Berkouwer, 1963:240). This question of Berkouwer's is indeed fundamental to theological thought on the consummation. Theologians over a wide spectrum hold that much more research in this regard should be done (e.g. Brunner, 1950:358; Van Niftrik, 1953:163; Kuyper, 1902: 276). In his work on eschatology Dijk (1953:204) also poses a number of questions on the position of Christ after his Second Coming: what will be his task in the New World? Will the Father still rule through him over all things? Will he remain our intercessor with the Father? Will he still be the Head of his Church? (cf. Dijk, 1953:204).

\section{Mediatory reign}

It will, however, be essential first of all to get a brief perspective on the

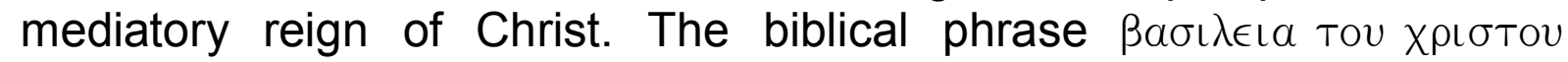
denotes the dominion of Christ founded in the eternal decree of God. Thus the mediatory reign should always be considered in organic coherence with Christ's office of Mediator. This is particularly obvious where Holy Scripture depicts him as King in the stature of a servant. He fulfilled this office in full dependence on and obedience to God. He reigned for God and on behalf of God, since as the Christ incarnate he had received his $\beta a \sigma i \lambda \in \iota \alpha$ from the Father, the Son and the Holy Spirit. Indeed, the kingdom of God is in this world $(\epsilon \nu \tau \omega \kappa \circ \sigma \mu \omega)$, it is developing in this world, but its origin is not in the world. 
And yet, the kingdom of Christ is nothing but the kingdom of God. It is the dominion of God in the dispensation of grace. The dominion of Christ does not displace, let alone supersede, the rule of the triune God; the control of the whole world belongs to God.

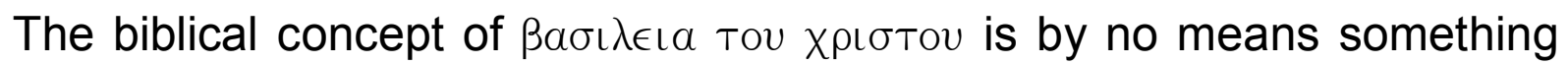
static; on the contrary, it is a dynamic and active rule, a progressive struggle with the powers of darkness, and their consequent subjugation to God by the power of the redemptive and reconciliatory work of Christ. Karl Ludwig Schmidt puts it in a nutshell by saying that the kingdom of God as his work among mankind is "eine soteriologische Angelegenheit ... deren Erklärung mit der Erklärung der Soteriologie überhaupt in der Verkündigung Jesu Christi und seiner Apostel steht und fällt" (see Schmidt, 1933:584). The presence of the kingdom is to be found in the

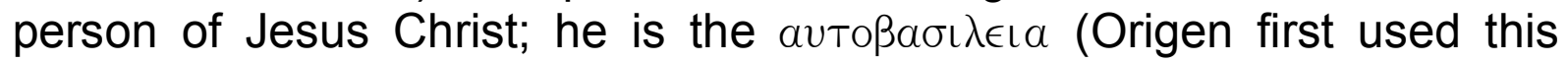
expression; cf. Ridderbos, 1950:99).

Primarily the kingdom of Christ is a spiritual rule in the hearts and lives of his disciples (Inst. 2.15.3). His kingdom comes where the will of God is done, on earth as it is in heaven (cf. Brunner, 1950:358). And yet, for this dispensation it is neither complete nor final. It calls for consummation. But the consummation of the kingdom of Christ is not an end in itself. It has a very specific function within the comprehensive kingdom of God, which extends over all places and times, and beyond in eternity.

\section{I Corinthians 15: a key?}

In the early sixties Berkouwer published a series of articles dealing in particular with the consummation of the kingdom of Christ in view of I Corinthians 15:28. He examined the ideas of a number of theologians: Cullmann (1946), for instance, stresses that the Son will eventually be incorporated into the Father. Van Ruler (1962) again maintains that in the end Christ will lay down his human nature, which is, in his view, not incorruptible. Calvin (1559) states that Christ, "having accomplished the office of Mediator, shall cease to be the vicegerent of the Father and will be content with the glory which he possessed before the world was ... His giving up of the kingdom to the Father, so far from impairing his majesty, will give a brighter manifestation of it. God will then cease to be the Head of Christ, and Christ's own Godhead will then shine forth of itself, whereas it is now in a manner veiled" (Inst. 2.14.3; see ). Both Kuyper (1929) and Bavinck (1967) stated that Christ will retain his human nature in all eternity. Commenting on these views, Berkouwer held the opinion that for the present moment Christ is yet in his state of exaltation; then, however, his office of Mediator will be fulfilled. However, I Corinthians 15 does not imply that the Son will be incorporated into the 
Father. Handing over the kingdom will not be in weakness, but in superb victory (Berkouwer, 1962). Verse 28 portrays the final consummation of his Messianic assignment (Berkouwer, 1963:250): the eschaton will be dominated by the theocentric stature of the Lamb (Berkouwer, 1963: 254).

Incidentally, the prominent use of the name Lamb of God for the Son in the Book of Revelation is a clear indication that his basileia of this world has come to an end. He will no longer be the mediator-king. And yet, it is an indication of the ever-remaining bond between him and his Church (Dijk, 1953:202).

A point that has been raised in connection with the handing over of the kingdom by Christ to the Father is whether it does not in any way support the idea of subordination of the Son to the Father. In his exposition of the Thirty Nine Articles Browne (1868) comments that we should not deduce from this passage in I Corinthians 15 that the Son will give up his human nature and that the human nature, devoid of the divine nature, will then be subjugated to the Father. Paul says that it is the Son who will be made subject to God, "but the human nature of Christ, separated from his divine nature, would not be the Son of God". The true interpretation is that the Son who is in his human nature subordinate to the Father, for the present as Mediator still rules over men, angels and nature. "But at the end, when the need of that mediatorial reign has passed away, the mediatorial sceptre shall be laid down, Christ shall reign with God upon his right hand" (Browne, 1868:71).

There is a considerable difference of opinion between theologians on the issue whether we can say that after the consummation of his kingdom, the Son will reign with God as Christ in his divine and human natures, or whether his dominion will be only as the eternal Son of God. As to the issue of subordination, Christ's turning over of the Kingdom to God should not be seen as an essential subordination of the Son to the Father. "Rather it is a functional subordination that characterizes trinitarian relationships" (cf. Disciple's Study Bible, p. 1467; Brunner, 1953: 227).

Grosheide (1957:402) points out that we should carefully note that the end ( $\tau$ o $\tau \in \lambda \hat{o}$, vs. 24), and thus the kingdom ( $\beta a \sigma \iota \lambda \in \iota \alpha)$, will come when the enemies of God's sovereignty have been destroyed. This is exactly what Christ has come for: to re-establish the sovereignty of God. When this has been achieved, he will present the $\beta a \sigma \iota \lambda \in \iota a$ to God (Grosheide, 1957:403). 


\section{Intermezzo}

Kuyper refers to this passage in I Corinthians 15 in a number of his works. He indicates that the office of Mediator only has a purpose while not yet everything has been subjugated; however, when every opponent has been conquered, the full programme for the Mediator will have been completed and he will be ready to account for it. As he has in obedience to God subjugated everything, he will also show his obedience by laying down his office of Mediator and handing the kingdom to the Father (Kuyper, De Christo III: 195 ff.; cf. Kuyper, 1929: 292).

Kuyper also remarks - and I think correctly - that mention of the Father in this context does not indicate the First Person in Holy Trinity, but indeed the triune God, Father, Son and Holy Spirit (Kuyper, De magistratu: 186). There are indeed several instances in Scripture where the name Father is used metaphorically of God in his trinity. In this way Christ will remain king even after surrendering the $\beta a \sigma \iota \lambda \in\llcorner\alpha$, yet no longer as Mediator, but as eternal Son of God (Kuyper, De creaturis : A; De angelis : 37; see Dijk, 1953:207. König, 1980:306 and others reject the idea of Christ eventually forfeiting the office of Mediator).

In his study of I Corinthians 15, Karl Barth points out that Christ will accomplish his task by the resurrection of those belonging to him. This action - the complete destruction of death - will be his most sublime and final act of dominion. But for the present dispensation it has not yet been completed. There still remains a conflict between his power and that of the opponents of his kingdom. Living in his kingdom, we await its consummation. "When it is fulfilled, then His Kingdom, as a special Kingdom beside the Kingdom of God, is at an end." But currently it is merely an "adjacent" Kingdom of God, the period of hope, which is indeed hope, but no more than hope. Therefore, says Barth, "this 'God all in all' and hence the general resurrection of the dead, is the meaning of the Christian faith". The dominion of Christ cannot come to an end until God has subjugated everything to it (Barth, 1933:173 ff.).

In his commentary on verse 24 Pop (1978) states that the consummation of Christ's work is just this: to deliver the kingdom to God the Father. It is the culmination of Christ's work. He was anointed to bring to its true reality the kingdom of God among all humankind and throughout creation. Both in his humiliation and in his exaltation he manifested the kingdom of God. When he has fulfilled his charge on the last day, He will deliver to the Father the kingship to which God delegated him. No longer will there be any need for an intermediate king between God and humankind. Commenting on verse 28, he states that Christ will then still be the Son of God, but his work of mediation will have come to an end. 
The kingdom of Christ will make room for the kingdom of God. The intermediate work of the Son will no longer be between God and his world, but all love of God, the Father, the Son and the Spirit will be over and in all that live (Pop, 1978:379).

Cullmann also develops the notion of an intermediate kingdom. The kingdom of Christ has, exactly like the Church, a point of commencement and an end. "Das Reich Christi is zeitlich gesprochen noch nicht das Reich Gottes, das erst am Ende, wenn Christus Gott alles unterworfen haben wird, das Reich Christi ablösen wird" (Cullmann, 1946:184; cf. Schlatter, 1956:414). There is no way in which the dominion over the whole of creation cannot eventually be in the hands of God Almighty. From the very beginning man denied God his glory. For this reason he sent his Son into the world with the mandate to rule and to rectify the situation. I Corinthians 15:24 gives us the assurance that it will indeed be so and that it will be acknowledged by all. This is what Delling had in mind: "Es geht Paulus zuletzt um Gottes Gottsein - seine $\delta \circ \xi \alpha$ " (Delling, 1970:96).

This trend of thought is also developed by Moltmann (1979) where he states that the mission of Christ is consummated in the glorifying of believer and of creation. "In that glorification and with that glorification Christ arrives at his own glorification." In this the Son glorifies the Father. "The Son is glorified through the glory, into the glory, and for the sake of the Father's glorification." At the same time, however, it is also the work of the Holy Spirit. It is he who glorifies Christ in us and us in Christ for the glory of God the Father. In this line of thought Moltmann comes to the conclusion that "the trinitarian history of glorification leads to the eschatological unity of God" (Moltmann, 1979:89 ff.). And for that very reason he can also say that the present reign of Christ can only be an "eschatologischer Vorläufigkeit der Allein- und Allherrschaft Gottes" (Moltmann, 1966:148).

On the final work of Christ, I would also like to quote from the commentary of Fee (1987:754 ff.): "The resurrection of the dead will mean that Christ has subjugated, and thereby destroyed, the final enemy death, expressed in this case in the terminology 'every dominion' and 'every authority and power"'. That this destruction of the "powers" refers to the defeat of death is made certain by the supporting argument from Scripture that follows. On the other hand, with the final defeat of the last enemy the subjugation of all things has taken place, so that Christ might turn over the rule to God the Father (Fee, 1987:754) ... Paul's point is that in raising Christ from the dead God has set in motion a chain of events that must culminate in the final destruction of death and thus of God's being once again, as in eternity past, "all in all' (Fee, 1987:759) ..." 
In Paul's view the consummation of redemption includes the whole sphere of creation as well. Nothing lies outside God's redemptive purposes in Christ" (Fee, 1987:760). It is particularly important to note that the final victory of Christ is over death itself. This having been achieved, the need for the intermediate rule and combat of Christ no longer exists.

Conzelmann (1969) makes the point that God delegated his $\beta a \sigma i \lambda \in \iota \alpha$ to Christ for a definite period, from the raising of Christ to his parousia, and for a definite end, the annihilation of the hostile powers. During the messianic age Christ accordingly exercises the sovereignty of God in a specific area. When this commission has been fulfilled, God once more rules alone and directly. Then God will once more directly exercise his total sovereignty (Conzelmann, 1969:271).

\section{Eschatological perspective}

It has been indicated that according to Scripture there is a very definite eschatological perspective to Christ's office of Mediator. To quote Ridderbos: the preaching of the kingdom and the King reaches out to the end; it embraces all nations and will be present until the consummation of the world (Ridderbos, 1956:302).

In his love for fallen mankind God has ordained the way of salvation. In this regard Cullmann sees a very clear line in the life and work of Christ:

Christus der Mittler der Schöpfung - Christus der leidende Gottesknecht als Erfüller der Erwählung Israels - Christus der gegenwärtig herrschende Kyrios - Christus der wiederkehrende Menschen-sohn als Vollender allen Geschehes und Mittler der Neuschöpfung (Cullmann, 1948:94).

In the consummation of his office as Mediator the кaıpô is there for handing over the kingdom to the triune God.

This will be a day of judgement, which will also be the moment of final and indisputable victory for Christ. "The Kingdom of God moves on to its inevitable triumph: the unconditional surrender of the Foe, the restoration of all creation under the divine domain, and the submission of all powers in heaven and earth to the name of Christ" (Bright, 1953:233). As we have indicated, the last foe that Christ will defeat, is death. By it the purpose of Christ's mediatorial reign will have been accomplished. As indisputable King he will be able to present an immaculate Kingdom as evidence of the consummation of his work. Thus his messianic office as Prophet and Priest, but particularly as King, will be completed. 


\section{The humanity of Christ}

There is difference of opinion among theologians on the duration of Christ's humanity. Is the implication of his handing over the basileia to the Father also the end of his human nature? Obviously, he did not have a human nature from all eternity. Will he retain it after the consummation of his kingdom? Kuyper (De Christo III: 196), Bavinck (1967, III:481) and many other Reformed theologians do hold that he will retain his humanity in all eternity. Dijk argues that should Christ forfeit his human nature, the Church as his body will be without a Head, and that there is only one option: He will be Jesus in all eternity (Dijk, 1953:213).

But there is another view: Van Ruler, for instance, maintains that Christ will relinquish his human nature at the end of this dispensation (Van Ruler, 1962; cf. Van Ruler, 1947:149 ff.). His idea of a messianic intermezzo was severely criticised by Velema, who holds that our humanity was saved by Christ, and even after his second coming it will not lose its likeness to Christ as true image of God (Velema, 1992:352). On the other hand, the office of Christ as Mediator is unquestionably linked to his humanity. Hence it is indeed a valid question whether the consummation of his reign as Mediator does not inevitably comprise the termination of his human nature. For the present this issue still remains an open question in Reformed theology.

Since Christ's office of mediation can be regarded as a perfection of the general office of believers, another valid question is whether we will still occupy this office after the consummation. To my mind the answer is no. Presently we live by faith; then, according to Paul, we shall see face to face (2 Cor. 5:7; 1 Cor. 13:12). Yes, the Son of God will still be the Head of his Church; we will still know that Christ was our Redeemer; but we will know him as the Lamb of God in the stature of the eternal Son of God.

My conclusion is that there is indeed enough evidence to say that our view on the consummation should be theocentric rather than Christocentric; that indeed in the next dispensation Christ will no longer serve in the office of Mediator; neither will we serve in the office of believers. Christ will no longer be King-as-mediator; neither will we be kings-asbelievers. He will be the Son and no longer Servant of the Lord; we will be children of God and no longer servants of his kingdom (cf. Rev. 21:6; Rom. 8:14-17; 23-25; Eph. 1:5). But again: his being Son will be fundamentally different from our being children. He will be Son of God in ontological sense; in our case it will be a restoration of the position that man, created in the image of God, was endowed with before the Fall; even more than that, as sin will no longer be a possibility. After the 
consummation $\mathrm{He}$ will be Son of God according to the character of his being, but we will be children of God, the Father, the Son and the Holy Spirit on account of the atonement of Christ.

\section{Bibliography}

BARTH, K. 1933 The resurrection of the dead. (Transl. Stenning). London : Hodder \& Stoughton.

BAVINCK, H. 1967. Gereformeerde Dogmatiek. Kampen : Kok.

BERKOUWER, G.C. 1962. I Kor. 15:28 - Een sleutel? Gereformeerd Weekblad, 17:34-39.

BERKOUWER, G.C. 1963. De wederkomst van Christus, deel II. Kampen : Kok.

BRIGHT, J. 1953. The Kingdom of God. Nashville : Abingdon.

BROWNE, H. 1868. Exposition of the Thirty Nine Articles. London : Longmans.

BRUNNER, E. 1950. Dogmatik, Band 2. Die Christliche Lehre von Schöpfung und Erlösung. Zurich : Theologischer Verlag.

BRUNNER, E. 1953. Das Ewige als Zukunft und Gegenwart. Zürich : Zwingli Verlag.

CALVIN, J. 1559. Institutio Christianae religionis. (Transl. H. Beveridge. 1845. Edinburgh : Calvin Translation Society.)

Cat. Lect.

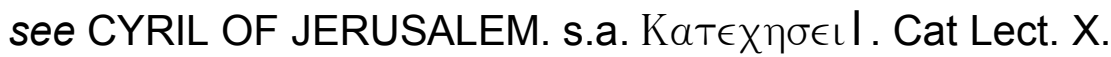

CONZELMANN, H. 1969. Der erste Brief an die Korinther. Gottingen : Vandenhoeck.

CULLMANN, O. 1948. Christus und die Zeit. Zürich : Evangelischer Verlag.

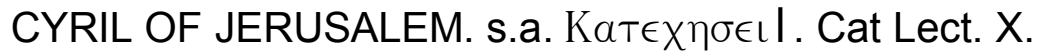

De angelis see Kuyper, A. s.a.

De Christo III see Kuyper, A. s.a.

De creaturis see Kuyper, A. s.a.

De Magistratu see Kuyper, A. s.a.

DELLING, G. 1970. Zeit und Endzeit. Neukirchen-Vluyn : Neukirchener Verlag.

DIJK, K. 1953. De toekomst van Christus. Kampen : Kok.

DISCIPLE'S STUDY BIBLE. 1988. Nashville : Holman.

FEE, G.D. 1987. The First Epistle to the Corinthians. NICNT. Grand Rapids : Eerdmans.

GROSHEIDE, F.W. 1957. De eerste brief aan de Kerk in Korinthe. Kampen : Kok.

KÖNIG, A. 1980. Jesus die laaste. Pretoria : NGKB.

KUYPER, A. 1902. De gemene gratie. Leiden : Donner.

KUYPER, A. 1929. Van de voleinding. Kampen : Kok.

KUYPER, A. s.a. Dictaten Dogmatiek. De angelis. s.I. : s.n.

KUYPER, A. s.a. Dictaten Dogmatiek. De Christo. s.I. : s.n.

KUYPER, A. s.a. Dictaten Dogmatiek. De creaturis. s.I. : s.n.

KUYPER, A. s.a. Dictaten Dogmatiek. De magistratu. s.I. : s.n.

MOLTMANN, J. 1966. Theologie der Hoffnung. München : Kaiser.

MOLTMANN, J. 1979. The future of creation. London : SCM.

POP, F.J. 1978. De eerste brief van Paulus aan de Corinthiërs. Nijkerk : Callenbach.

RIDDERBOS, H.N. 1956. Koninkrijk der hemelen. (In Christelijke Encyclopedie, IV.

Kampen : Kok. p. 300-303.)

RIDDERBOS, H.N. 1950. De komst van het Koninkrijk. Kampen : Kok. 
SCHLATTER, A. 1956. Paulus der Bote Jesu. Stuttgart : Calwer.

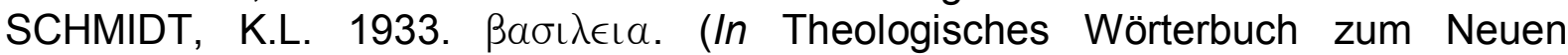
Testament (ThWNT). Herausgegeben von Gerhard Kittel. Stuttgart. I: 579-595.)

VAN GENDEREN, J. \& VELEMA W.H. 1992. Beknopte Gereformeerde Dogmatiek. Kampen : Kok.

VAN NIFTRIK, G.C. 1953. Kleine Dogmatiek. Nijkerk : Callenbach.

VAN RULER, A.A. 1947. De vervulling der wet. Nijkerk : Callenbach.

VAN RULER, A.A. 1962. De verhouding van het kosmologische en het eschatologische element in de Christologie. Nederlands Theologisch Tijdschrift (NThT), 16:196-217.

VELEMA, W.H. 1992. De mens het beeld God's. (In Van Genderen, J. \& Velema, W.H. Beknopte Gereformeerde Dogmatiek. Kampen : Kok. p. 292-353.)

\section{Key concepts:}

consummation of the kingdom

eschatology

humanity of Christ

kingdom of Christ

Mediator

\section{Kernbegrippe:}

eskatologie

koninkryk van Christus

menslike natuur van Christus

Middelaar

voleinding van die koninkryk 


\title{
Response
}

\section{The consummation of the kingdom of God A response to the paper of P.C. Potgieter}

\author{
G.J.C. Jordaan \\ School for Biblical Sciences and Bible Languages \\ Potchefstroomse Universiteit vir $\mathrm{CHO}$ \\ POTCHEFSTROOM \\ E-pos: sbbgjcj@puknet.puk.ac.za
}

\begin{abstract}
The consummation of the kingdom of God. A response to the paper of P.C. Potgieter

In his investigation of the consummation of God's kingdom Potgieter made the wise decision to take 1 Corinthians 15:24-28 as the point of departure. However, this approach requires that a thorough exegesis be made of the particular passage, in which respect Potgieter's paper is not not sufficient. Nevertheless, using this approach Potgieter succeeded in drawing a clear line from the reign of Christ to the final reign of God the Father. Potgieter's viewpoint that Christ, when handing over the kingdom to the Father, will also lay down his office as Mediator, is questionable. From passages such as Romans 8:17 and Ephesians 2:6 it seems as if Christ, even after the consummation, will remain Mediator in the sense that through his mediation we shall be God's children in eternity and be glorified by God.
\end{abstract}

\section{Introduction}

Appreciation is due to Prof. Potgieter for a fresh and original approach to a very difficult topic about which so little is known that everyone who speaks about it can do so only with great hesitation. Therefore the attempt to formulate critical remarks in this response is also made with great hesitation. 
In a paper about the consummation of God's kingdom one would normally expect to be presented with a synthesis of the Scriptural revelation about the things that are to happen at the second coming of the Lord, things like the resurrection of the dead, the judgment of the world, and God's eternal reign of the new heaven and the new earth. However, instead of attempting to cover the entire field in a single paper, Potgieter has decided to delimitate his study to one very specific aspect within the field of investigation, viz. the question about the position of Christ at the final consummation of the kingdom, especially Christ's relation to the Father. The unfortunate result is, however, that the contents of the paper is not really true to its title. Therefore my first recommendation is that the title should be changed or at least be expanded by a fitting subtitle.

Nevertheless, Potgieter's decision to restrict his paper to only one aspect of the topic is commendable, since the depth and profoundness in which he discusses this single aspect outweighs the lack of completeness and elaboration.

Furthermore has chosen to take 1 Corinthians 15:24-28 as point of departure for his investigation. A wise decision, to my mind, because this passage is indeed one of the basic sources of information about the consummation of the kingdom of God, as proven by the fact that scholars writing on the topic of the consummation almost without exception take special note of 1 Corinthians 15 (e.g. Ridderbos, 1971: 68 ff.; Berkhoff, 1926:131; Bright, 1953:233; Dijk, 1953:205 ff.; Berkouwer, 1963:239 ff.; Cullmann, 1958:300 ff.). Cullmann (1958:300), of course, goes too far in his statement that 1 Corinthians 15 is "der Schlüssel für alle neutestamentliche Christologie". To take this passage as the key to all New Testament Christology, is rather an overstatement. One has to be careful not to isolate 1 Corinthians 15 from the rest of the New Testament revelation as if only this passage speaks about the position of Christ at the consummation of the kingdom. Ridderbos (1971:628) in this regard warns that the teaching about Christ and the Father in 1 Corinthians 15 should not be viewed as an eschatological extra, i.e. as something not taught elsewhere in Scripture, but merely as a specific aspect of the great future, formulated by Paul in a manner which addressed his readers at best. By means of this we are reminded of two basic rules in Reformed hermeneutics:

- Firstly, the practice of comparing Scripture with Scripture.

- Secondly, reading every passage within its textual context and sociohistorical context. 
I do not say that Potgieter in his paper has entirely neglected these matters, but since he presents his paper as a study of one specific Scriptural passage, he could have made more of exegetical matters. In its present form, the paper mainly consists of a critical presentation of the viewpoints of different scholars and commentators about the teaching of 1 Corinthians 15 regarding the consummation of the kingdom. If Potgieter's criticism had been more soundly based on exegetical grounds, the paper could have been even more valuable. But let me leave it at that, since I have to respond not to what is omitted but to what is written in the paper itself.

In the paper Potgieter, taking 1 Corinthians 15:24-28 as his "text", draws certain conclusions and also poses some questions - all in respect to the status of Christ at the consummation of the kingdom. I shall now briefly go through some of these conclusions and questions, making responding remarks as I proceed.

\section{Christ's office as Mediator at the consummation}

Potgieter maintains that at the consummation of the kingdom Christ will relinquish his office as Mediator. With Kuyper he argues that when Christ hands over the kingdom to the Father, the full programme for the Mediator will have been completed and his office will come to an end. So when verse 24 refers to "the end" ( $\tau \mathcal{F}_{T} T \dot{\lambda} \mathrm{\lambda OS}$ ), it also includes the end of Christ's office as Mediator.

However, in 1 Corinthians 15 it is not explicitly said or even suggested that Christ's office as Mediator will come to an end. One can only make the conclusion by way of deduction. Such a deduction will have to depend on information from elsewhere in Scripture. Dijk (1953:206) suggests a parallel to Jesus' last words on the cross as in John 19:30: "It is finished" ( $T \in T \in \lambda \epsilon ́ \sigma T \alpha L)$, i.e. Jesus' purpose as Mediator has been attained by his humiliation and death on the cross. This meaning of $\tau \in T \in \lambda \epsilon^{\prime} \sigma T a$ l is explained by Jesus Himself in John 17:4: "I have completed ( $\tau \in \lambda \in \mathrm{L}(\hat{\omega} \sigma a S)$ the work which you gave me to do". Thus at Calvary Christ completed the Mediatory commission for which purpose

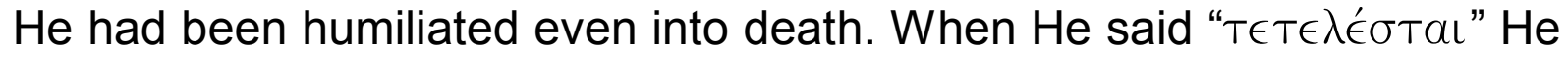
declared his work as humiliated Mediator to have come to an end.

But it was not the end of his office as Mediator. After his resurrection and ascension He became the exalted Mediator, continuing his office from the right hand of the Father. About this we read in Ephesians 1:20-23, for example. According to Potgieter this continued office of Christ is directly related to his commission to subject all powers and to re-establish the sovereignty of God. And hence, he argues, when Christ will hand over 
the kingdom to the Father, his office as Mediator will come to a final end. I do agree that inasmuch as Christ's office as Mediator can be related to his subjecting his enemies and re-establishing God's sovereign rule, his office will be fulfilled and therefore will come to an end. This is what the passage from 1 Corinthians 15 is about. However, I do not think that Christ's office as exalted Mediator is restricted to this one aspect.1 As indicated in passages such as 1 Timothy 2:5, Romans 8:17 and 2 Corinthians 5:17, Christ as exalted Mediator is not only Mediator of our prayers but also Mediator of our being children of God and Mediator of our being new creatures in the eschaton. Therefore I question the viewpoint that Christ, when handing over the kingdom to the Father, will have completed his office as Mediator. On the matter of his office as exalted Mediator I shall return later.

\section{Will Christ relinquish his human nature?}

Proceeding from his conclusion that Christ's office as Mediator will come to an end, Potgieter poses the question whether Christ's humanity will also come to an end at the consummation (p. 8). He refers to theologians such as Kuyper, Bavinck, Dijk and Velema who hold the view that Jesus will retain his human nature for eternity. Potgieter himself seems to tend towards the view of Van Ruler, who maintains that Christ will relinquish his human nature at the end of this dispensation. I quote Potgieter on page 8 of his paper:

The office of Christ is unquestionably linked to his humanity. Hence it is indeed a valid question whether the consummation of his reign as Mediator does not inevitably comprise the termination of his human nature.

To my mind it is not such an inevitable consequence, especially when we take into consideration Greijdanus' commentary on 1 Corinthians 15:28, where he states that Christ's human nature will remain, because it is in his human nature that Christ will subject Himself to the Father after handing over the kingdom. However, also Greijdanus' remark seems to be a deduction, because in the text no reference to the human nature of Christ is found.

Potgieter indeed puts his question about the human nature of Christ in a very cautious manner, by saying (p. 9): "For the present this remains an open question in Reformed theology." Perhaps Reformed theologians should not be too hopeful or daring to find an answer, because Scripture

1 Calvin maintained that Christ's office as Mediator was restricted to our salvation (Schroten, 1948: 481), which to my mind is narrowing it down too much. 
itself seems unwilling to provide us with an answer to this question. Therefore, in asking whether Christ will lay down his human nature at the consummation of his kingdom, we are enquiring about matters that were perhaps intended to remain hidden to us, as Ridderbos (1971:629) calls it. Dijk (1953:208) remarks: "Dieper kunnen wij in deze weelde niet indringen".

\section{Will Christ still reign after the consummation?}

The next conclusion formulated by Potgieter is that in the following dispensation Christ will still reign, but not any more as Mediator-King. His reign will be the reign of God, since as the Son of God, He is eternally One with God the Father, the Son and the Holy Spirit. With this conclusion I can agree completely, since, when comparing Scripture with Scripture, quite a number of passages are found in which Christ's eternal reign is revealed, for example:

\section{Luke 1:33 His kingdom will never end.}

Rev. 22:1-5 which repeatedly refers to the throne of God and of the Lamb, to reign for ever and ever.

However, as 1 Corinthians 15:24-28 teaches us, in the end Christ will hand back to God his kingdom, i.e. the power in heaven and on earth (Matt. 28:18) which Christ had received to complete his Messianic mission of re-establishing God's kingdom. Thus when Scripture teaches that Christ will reign forever, it does not refer to his reign as MediatorKing, but it refers to his eternal reign with God after handing over his reestablished kingdom to Him.

\section{Consequences for the believers}

Potgieter finally comes to conclusions about the consequences which the handing over of the kingdom will have for believers. Also these conclusions are not taken directly from the text of 1 Corinthians 15, but argued from it.

- Potgieter maintains that after the consummation we shall no longer serve in the office of believers. He links this conclusion to his earlier conclusion that Christ will no longer serve in the office as Mediator. Although it can be agreed that at the consummation of the kingdom the office of believers will come to an end, the argument for this conclusion nevertheless should rather be taken from Scripture itself. An enlightening place to start, is Hebrews 11:1, where faith - belief is defined as "being certain of what we do not see". Such is the faith in which we presently live while being in the office of believers. This definition of faith is expanded in Romans 8:25 as "hope in what we 
have not seen". But in 2 Corinthians $5: 7$ and 1 Corinthians 13:12 (quoted by Potgieter in another respect) it is written that one day - i.e. in the day of the consummation - we shall see face to face. So we shall no longer live in faith, believing in things unseen, but we shall live by sight. Exactly how this will be, is not revealed; but that it will be, is revealed indeed.

- Secondly, Potgieter makes the deduction that we shall not need Christ as Mediator any more - of course in line with his previous conclusion that Christ will cease to be Mediator. Since I question that previous conclusion, I also question the deduction that we shall no longer need Christ as Mediator. As motivation I refer to other texts from Pauline writings in which our being in Christ is taught as an eschatological reality. See for example Romans 8:17, where Paul writes that we who are in Christ, having shared in his sufferings, will also share in his glory; also Ephesians 2:6 which teaches us that we shall be seated in the heavenly realms in Christ.

In the light of the in Christ-passages one could perhaps give more serious consideration to the view of Dijk (1953:213-214) that at the consummation, although we shall not need the mediation of Christ with regard to the payment for our sins (which He completed on the cross at Calvary), nor his mediation for our prayers (which comes to an end once we stand before God face to face), we shall still need his mediation because in Him we can be God's children in eternity. Furthermore we shall be glorified by God only because we shall be in Christ (Rom. 8:17), i.e. through Christ's mediation (cf. Floor, 1981:78).

But, once again, perhaps this enquiry is about things which God in his wisdom decided to hide from our view until the day when we see face to face.

- In the third place, Potgieter concludes that, just as Christ will be Son of God in ontological sense, we will be restored to the position that man, created in the image of God, was endowed with before the Fall. Of course this is a very terse and hence a rather cryptic remark which could be misinterpreted. Perhaps it would be clarifying if Potgieter should briefly explain that the restoration "to the position of man before the Fall" does not add up to a complete return to the situation before the Fall. At the consummation sin and death and Satan himself will have been conquered, so that we shall enter a new situation, without the pre-Fall possibility of sin and death.

Having made these few critical remarks, it has to be repeated that Potgieter deserves much appreciation for the way in which he has 
approached this topic. In particular the neat and fresh contribution of a Christological-Theocentric approach to this topic should be appreciated. Potgieter's basic statement that the consummation of the kingdom should be viewed from a Theocentric perspective rather than a Christocentric perspective (p. 4), is clarified by the way in which he artfully draws the line from the reign of Christ to the final reign of God. Indeed, Potgieter's paper proves that the consummation of God's kingdom should be seen from a Christological-Theocentric angle.

\section{Bibliography}

BERKHOFF, A.M. 1926. De wederkomst van Christus. De adventslijn der Heilige Schrift tot Openbaring 19. Kampen : Kok.

BERKOUWER, G.C. 1963. Dogmatische Studiën. De wederkomst van Christus II. Kampen : Kok.

BRIGHT, J. 1953. The Kingdom of God. New York : Abingdon.

CULLMAN, O. 1958. Die Christologie des Neuen Testaments. Tübingen : Mohr.

DIJK, K. 1953. De toekomst van Christus. : Kok.

FLOOR, L. 1981. Perspektiewe op die prediking van Paulus. Pretoria : NG Kerkboekhandel.

RIDDERBOS, H. 1971. Paulus, ontwerp van zijn theologie. Kampen : Kok.

SCHROTEN, H. 1948. Christus, de Middelaar, bij Calvijn. Utrecht : Den Boer. 
